\title{
A MAGYARORSZÁGI FELNÔTT NÉPESSÉG DROGHASZNÁLATA - AZ ORSZÁGOS LAKOSSÁGI ADATFELVÉTEL AZ ADDIKTOLÓGIAI PROBLÉMÁKRÓL 2015 (OLAAP 2015) REPREZENTATÍV LAKOSSÁGI FELMÉRÉS ALAPJÁN
}

\section{PAKSI BORBÁLA ${ }^{1}$ - DEMETROVICS ZSOLT ${ }^{2}$ - MAGI ANNA ${ }^{2,3}$ - FELVINCZI KATALIN ${ }^{2}$}

\author{
${ }^{1}$ Eötvös Loránd Tudományegyetem, Neveléstudományi Intézet \\ ${ }^{2}$ Eötvös Loránd Tudományegyetem, Pszichológiai Intézet \\ ${ }^{3}$ Eötvös Loránd Tudományegyetem, Pszichológiai Doktori Iskola \\ E-mail: demetrovics.zsolt@ppk.elte.hu
}

Beérkezett: 2018. augusztus 4. - Elfogadva: 2018. november 21.

Háttér és célok: Magyarországon 2001-ben (ADE 2001), 2003-ban (ADE 2003) és 2007-ben (OLAAP 2007) készült a felnôtt népesség körében célzott drogepidemiológiai adatfelvétel. A magyar népesség addiktológiai problémáinak feltérképezésére/nyomon követésére nyolc év kihagyás után 2015-ben készült újabb célzott vizsgálat. Tanulmányunkban az Országos Lakossági Adatfelvétel Addiktológiai Problémákról (OLAAP 2015) címú kutatás drogfogyasztással kapcsolatos eredményeit mutatjuk be.

Módszer: A vizsgálat a 18-64 éves népesség bruttó 2477, nettó 2274 fốs, országos reprezentatív mintáján készült, a 18-34 éves fiatal felnốtt populáció felülreprezentálásával. A 18-64 éves súlyozott minta nagysága 1490 fö. Az adatfelvétel a kérdezettek személyes megkeresésével, ún. „kevert”, a személyes kérdezést (face to face) és önkitöltốs elemeket egyaránt alkalmazó módszerrel, 2015 tavaszán zajlott. A drogfogyasztással kapcsolatos kérdések kialakítása a hazai elözményekre (Paksi, Rózsa, Kun, Arnold és Demetrovics, 2009), az EMCDDA modellkérdốveire (EMQ) (EMCDDA, 1999, 2002) és aktuális indikátorigényeire/ajánlásaira (EMCDDA, 2015b), továbbá az európai országok drogepidemiológiai vizsgálatainak metaanalizisére (Decorte, Mortelmans, Tieberghien és De Moor, 2009) támaszkodik. Az adatok feldolgozása az EMCDDA (2002) standardok szerint történt.

Eredmények/következtetések: A kutatás eredményei szerint a magyarországi 18-64 éves népességben minden tízedik válaszoló $(9,9 \%)$ fogyasztott már valamilyen tiltott szert az élete során. A tiltott drogok éves prevalenciaértéke 2,3\%, a havi prevalenciaértéke pedig 1,2\%. A legtöbben marihuánát/hasist fogyasztottak eddig életük során, ezt követi az ecstasy, a szintetikus-kannabinoidok, az amfetamin és az új stimulánsok népszerüsége. A drogokkal való kapcsolatba kerülés társadalmi-demográfiai kockázati tényezôit vizsgálva a droghasználat korosztályos és urbanizációs mintázódása mellett a kulturális/gazdasági státus, valamint az impulzivitás szerepét kell kiemelnünk.

Kulcsszavak: drogfogyasztás, lakossági vizsgálat, reprezentatíu felmérés, Magyarország 


\section{BEVEZETÉS}

A nemzetközi ajánlások (EMCDDA, 2009a, 2009b; Hibell és mtsai, 2000; Decorte, Mortelmans, Tieberghien és De Moor, 2009) a pszichoaktív szerhasználattal kapcsolatos általános populációs kutatások legalább négyévenkénti megismétlését javasolják, s felhívják a figyelmet arra is, hogy azokban a periódusokban, amikor a probléma intenzív változása feltételezhetố, különösen fontos a vizsgálatok rendszeres - akár kétévenként történô - ismétlése. A jelen tanulmányban bemutatásra kerülô vizsgálatot megelôzôen a magyarországi felnôtt népesség körében 2007-ben készült utoljára a különbözô szerhasználó magatartások és viselkedési addikciók vizsgálatára irányuló célzott epidemiológiai adatfelvétel (OLAAP 2007) (Paksi, Rózsa, Kun, Arnold és Demetrovics, 2009). A 2007 és 2015 közötti idôszakra vonatkozóan nem ismerjük az addiktológiai problémák tekintetében a felnôtt népesség körében lezajló magyarországi tendenciákat, holott az ezekre az évekre vonatkozó nemzetközi jelentések az európai droghelyzet változásáról, a drogfogyasztás epidémiájának jelentôs átalakulásáról, a drogprobléma összetettségének növekedésérôl, új pszichoaktív szerek, új populációk, új hozzáférési formák megjelenésérốl számolnak be (pl. EMCDDA, 2015a, 2016). Magyarországon a 2007-es lakossági vizsgálat óta eltelt években az iskolás populációban készült kutatások (Elekes, 2012, 2016; Hibell és mtsai, 2012; European School Survey Project on Alcohol and Other Drugs [ESPAD] Group, 2016; Németh és Költố, 2011, 2014) a drogfogyasztás elterjedtsége és/vagy struktúrája tekintetében szintén intenzív, de a nemzetközi tendenciáktól több tekintetben eltérô változásokat jeleztek, ami különösen is indokolttá teszi az általános populációban a pszichoaktív szerhasználat terén zajló folyamatok monitorozását.

Jelen tanulmányban az Országos Lakossági Adatfelvétel az Addiktológiai Problémákról 2015 (OLAAP 2015) vizsgálat droghasználattal kapcsolatos eredményeit mutatjuk be. Elốször általában a tiltott droghasználat, illetve a különböző tiltott drogok elterjedtségét, valamint együttjárását, a polidroghasználat elôfordulását vizsgáljuk, majd az elsố droghasználat életkori jellemzóivel, az egyes korévekben jelentkezố lakossági kockázatokkal foglalkozunk. Ezt követôen a tanulmány röviden kitér a különbözô tiltott szerek fogyasztásával és hozzáférhetôségével kapcsolatos percepciókra, valamint a fogyasztásnak való kitettségre vonatkozó új indikátorok (EMCDDA, 2015b) mentén kapott eredményekre. A következô részben a droghasználat társadalmi-demográfiai, illetve pszichológiai jellemzốk mentén mutatkozó mintázódásait elemezzük. A társadalmi mintázódások vizsgálata során elsôsorban a strukturalista/funkcionalista elméletek, azon belül a társadalmi/kulturális struktúrában való elhelyezkedéssel és az anómiával kapcsolatos magyarázatok, valamint az integrációs megközelítések (családi integráció, vallás, egyéb társas kapcsolatok) - esetenként az elméletek kapcsolódása, illetve az indikátorok különbözó értelmezései okán egymást átfedố indikátorai mentén mutatjuk be a társadalmi rizikótényezôk és megóvó faktorok érvényesülését (Paksi, 2007). A pszichológiai tényezốk vonatkozásában elsốdlegesen a pszichoaktív szer használatával gyakran összefüggésbe hozott impulzivitás és a különbözó pszichés tünetek vizsgálatára helyeztük a hangsúlyt. Az eredmények bemutatását az elmúlt közel másfél évtized tendenciáinak felvázolásával zárjuk. 


\section{MÓDSZER}

Az Országos Lakossági Adatfelvétel az Addiktológiai Problémákról 2015 (OLAAP 2015) reprezentatív lakossági felmérés módszertani háttere részletesen bemutatásra került egy önálló, a kutatás módszertani jellemzôit és eredményeit tárgyaló cikkünkben (Paksi, Demetrovics, Magi és Felvinczi, 2017). Jelen tanulmány módszertani részében csak az itt közölt eredményekhez közvetlenül kapcsolódó legfontosabb módszertani jellemzókre térünk ki.

\section{Minta és eljárás}

A kutatás célpopulációját a magyarországi 18-64 éves népesség, a mintavételi keretet az Közigazgatási és Elektronikus Közszolgáltatások Központi Hivatala (KEKKH) 2014. január 1-jei nyilvántartása szerint érvényes lakcímmel rendelkezô állandó lakosság képezte (6 583433 fő). Az adatfelvétel a keretpopuláció területi elhelyezkedés, urbanizációs fok és életkor szerint rétegzett (összesen 145 rétegbe sorolt), bruttó 2477 fôs országos reprezentatív mintáján zajlott, a 18-34 éves populáció felülreprezentálásával.

A kutatás során az alkohol- és drogfogyasztással kapcsolatos survey vizsgálatokra vonatkozó nemzetközi ajánlásokkal (WHO, 2000; EMCDDA, 2002; Decorte és mtsai, 2009) harmonizálva, a korábbi hazai kutatások adatfelvételi protokolljával (Paksi, 2003; Elekes és Paksi, 2004; Paksi és mtsai, 2009) megegyezô módon személyes megkereséssel zajló, kevert - azaz a személyes (face-to-face) kérdezési módszert önkitöltôs elemekkel kombináló - kérdezési technikát alkalmaztunk.

Az adatfelvétel 2015 tavaszán történt. Az elért nettó minta nagysága 2274 fő. A mintakiesések, valamint a fiatal felnôtt (18-34 éves) populációban alkalmazott felülreprezentálás (oversampling) korrigálására nem elemszámtartó, rétegkategóriák szerinti mátrixsúlyozást alkalmaztunk. A 18-64 éves népességre vonatkozó súlyozott minta nagysága 1490 fő, a minta elméleti hibahatára 95\%-os megbízhatósági szinten $\pm 2,54 \%$.

\section{A droghasználat elterjedtségének becslése során alkalmazott kérdések}

Az adatfelvételi battéria kialakításának kiindulópontját és módszertani megalapozását a 2007-ben készült OLAAP vizsgálat (Paksi és mtsai, 2009) képezte, ami a tiltott droghasználat vonatkozásában leképezte az EMCDDA modellkérdőívének (EMQ) (EMCDDA, 1999, 2002) ajánlásait, valamint harmonizált korábbi magyarországi általános populációs drogepidemiológiai vizsgálatokkal (Elekes, 2004; Elekes és Paksi, 2004; Paksi, 2003). Az OLAAP 2015 kutatásban a tiltott szerhasználattal kapcsolatos kérdések aktualizálása során a kétezres években Európában készült drogepidemiológiai vizsgálatok metaanalízisének (Decorte és mtsai, 2009) eredményeit, továbbá az EMCDDA - részben az említett metaanalízis tapasztalataival harmonizáló - indikátorigényének változásait (észlelt fogyasztás, észlelt hozzáférhetôség, fogyasztásnak való kitettség), illetve az új pszichoaktív szerek (ÚPSZ) használatának nyomon követésére 
az általános populációs vizsgálatok vonatkozásában megfogalmazott EMCDDA-ajánlásokat (EMCDDA, 2015b) vettük figyelembe.

Az tiltott drogokkal kapcsolatos adatok megbízhatóságát és érvényességét adatbázison belüli eszközökkel vizsgálva azt mondhatjuk, hogy némely szer esetében a prevalenciaértékek jelentôs inkonzisztens információt tartalmaznak, s a hiányzó, illetve érvénytelen válaszok aránya a semlegesnek tekinthetô szociodemográfiai kérdésekhez képest relatíve magas. A korábbi lakossági drogepidemiológiai vizsgálatokhoz (Paksi és mtsai, 2009) viszonyítva a mintavételen kívüli hibák kedvezótlen irányba mozdultak el (1. táblázat). Ugyanakkor a legelterjedtebb tiltott drogokkal kapcsolatos prevalenciaadatok fôként konzisztens információkat hordoznak, így az inkonzisztenciák a tiltott szerek összesített életprevalencia-értékébe viszonylag kis torzítottságot visznek, továbbá a mintavételen kívüli hibák jellemzôen nem mutatnak szignifikáns társadalmi-demográfiai mintázódást, azaz a kutatás a tiltott szerhasználat rizikófaktorainak megbízható becslését teszi lehetôvé (részletesen lásd: Paksi és mtsai, 2017).

1. táblázat. A tiltott drogokkal kapcsolatos válaszok megbízhatóságára és érvényességére utaló mutatók a 2007-es és a 2015-ös OLAAP-vizsgálatban (súlyozatlan adatok)

\begin{tabular}{|c|c|c|}
\hline & 2007 & 2015 \\
\hline \multicolumn{3}{|c|}{$\begin{array}{l}\text { Az inkonzisztens válaszok aránya a különbözô idejú prevalenciakérdésekben } \\
\text { (válaszolók \%-ában) }\end{array}$} \\
\hline Marihuána & 0,5 & 0,5 \\
\hline Ecstasy & 0,1 & 0,7 \\
\hline Amfetamin & 0,2 & 0,4 \\
\hline \multicolumn{3}{|c|}{$\begin{array}{l}\text { Az életprevalenciára és az elsố fogyasztásra vonatkozó kérdések alapján inkonzisztens } \\
\text { válaszok aránya a konzisztens fogyasztók százalékában }\end{array}$} \\
\hline Marihuána & 4,2 & 5,8 \\
\hline Ecstasy & 7,7 & 10,0 \\
\hline Amfetamin & 5,3 & 31,6 \\
\hline Kokain & 0,0 & 55,6 \\
\hline Heroin & 0,0 & 250,0 \\
\hline Egyéb opiát & 100,0 & 100,0 \\
\hline LSD & 22,2 & 44,4 \\
\hline Mágikus gomba & 40,0 & 83,3 \\
\hline \multicolumn{3}{|c|}{ Válaszhiányok és érvénytelen válaszok arányának alakulása (\%) } \\
\hline Tiltott drogokkal élés éves/havi prevalenciaértékei & $5-6 / \approx 9$ & $\approx 10 / \approx 13$ \\
\hline
\end{tabular}

\section{Szociodemográfiai és pszichológiai háttérváltozók}

A droghasználat szociodemográfiai mintázódásának vizsgálatakor a szokásos (életkor, nem, lakóhely, anyagi helyzet, háztartásméret stb.) jellemzók mellett az alábbi háttérváltozók kerülnek felhasználásra:

- Várható legmagasabb iskolai végzettség: A befejezett iskolai végzettség és a jelenleg végzett tanulmányok alapján képzett, a korábbi OLAAP-vizsgálatok során is (Paksi és mtsai, 2009) alkalmazott változó. 
- Végzettségi mobilitás: A kérdezett várható iskolai végzettségének elmozdulása nók esetében az anya, férfiak esetében az apa végzettségéhez képest (Róbert, 1990).

- Családi devianciák száma: A kérdezett szúkebb vagy tágabb családjában elôforduló szenvedélymagatartások vagy egyéb problémás viselkedések (dohányzás, rendszeres alkoholfogyasztás, sok nyugtató/altató fogyasztása, kábítószer-használat, szerencsejáték, öngyilkossági kísérlet, befejezett öngyilkosság, pszichiátriai kezelés) számát kifejezô, a korábbi OLAAP-vizsgálatok során is (Paksi és mtsai, 2009) alkalmazott változó.

- Anómia: Az anómia mértékét a - Srole és Seeman anómia-, illetve elidegenedésdefiníciójának egyes elemeit ötvözô (Robinson, Shaver, Wrightsman, 1991) normaszegés, a hatalomnélküliség, az orientációhiány és az elidegenedés dimenziói mentén, 4 fokú skálán (1 - egyáltalán nem ért egyet; 4 - teljesen egyetért) mérô, 10 itemet tartalmazó szubjektív indikátor (Andorka, 1994). Az alkalmazott mutató nagyobb értéke az anómikus érzületek fokozott jelenlétét jelzi.

- Deprivációs index: A többdimenziós hátrányos helyzet (Townsend, 1979) komplex jelzôszáma. Az általunk alkalmazott index 16 életkörülmény-komponensen alapul, ${ }^{1}$ az értéke az anyagi okokból hiányzó ${ }^{2}$ életkörülmény-komponensek számát fejezi ki. A mutatót anyagi okokból származó életkörülmény-hiányok indexének is nevezik (Kapitány, Spéder, 2004).

- WHO általános Jóllét skála: (Susánszky, Konoly, Stauder, Kopp, 2006) az egyének általános közérzetét vizsgálja 5 tétellel 4 fokú skálán $(0$ - nem volt jellemzô; 3 - nagyon jellemzô volt).

A drogfogyasztás pszichiátriai tünetek és az impulzivitás mentén mutatkozó mintázódásának vizsgálatára az alábbi mérôeszközök kerültek felhasználásra:

- Pszichiátriai tünetek: BSI - Rövid Tünetlista (Brief Symptom Inventory; Derogatis és Melisaratos, 1983; magyarul: Unoka, Rózsa, Kô, Kállai, Fábián és Simon, 2004) 27 tétele, melyekkel a BSI által vizsgált pszichés tünetek közül a depresszió, szorongás, ellenségesség, interperszonális érzékenység és a kényszer jelenlétét vizsgáltuk. A tételek együttesen az általános distressz szintjérôl adnak informáci-

\footnotetext{
A kutatás az EU deprivációs indikátorai (Fusco, Guio, Marlier, 2010; Guio, Gordon, Marlier, 2012) és az Életünk fordulópontjai címú hazai kutatási program különbözố hullámaiban alkalmazott indikátorok (Kapitány, Spéder, 2004; https://www.demografia.hu/hu/kutatoknak) alapján a következô 16 életkörülmény-komponens meglétét vizsgáltuk: egy lakás, amiben mindenkinek van egy külön szobája (1); WC és fürdôszoba vagy zuhanyzó a lakásban (2); automata mosógép (3); mosogatógép (4); LCD, plazmatelevízió ('lapos tv') (5); otthoni/saját internet-hozzáférés (6); asztali számítógép vagy laptop (7); okostelefon, táblagép (8); évente egy hétre elutazni valahova pihenni (9); rendszeresen vásárolhasson új ruhákat (10); lecserélhesse elöregedett bútorait, háztartási eszközeit (11); megfelelôen melegen tarthassa a lakását (12); havonta egyszer étteremben ebédelhessen (13); havonta egyszer meghívhassa barátait vacsorára (14); autó (a háztartásban valakinek személyes tulajdonában) (15); havonta valamennyit, legalább 10 ezer forintot félre tudjon tenni (16).

2 A válaszadók az adott életkörülmény-komponens meglétével, illetve hiányával kapcsolatos válaszukat, az alábbi lehetôségek mentén fejezik ki: 1 - rendelkeznek ilyen lehetôséggel; 2 - anyagi okok miatt nem rendelkeznek ilyen lehetôséggel, illetve 3 - más okból nem rendelkeznek vele.
} 
ót. A tüneteket a részt vevôk 5 fokú skálán értékelték, hogy a kérdezés elôtti egy hét során azok mennyire voltak jellemzőek rájuk (1 - egyáltalán nem; 5 - nagyon).

- Impulzivitás: BIS-11 - Barratt Impulzivitás Skála (Barratt Impulsiveness Scale) (Barratt, 1959; Patton, Stanford és Barratt, 1995; Kapitány-Fövény, Varga, Potenza, Griffiths, Székely, Paksi és mtsai, 2018) 21 tételes változata az impulzivitás 3 területét vizsgálja: a tervezés hiányát, a figyelmi, illetve a motoros impulzivitást 4 fokú skálán (1 - soha, alig; 4 - majdnem mindig, mindig).

\section{Az adatfeldolgozás módja}

Az elemzések a nemzetközi ajánlások és szakirodalmi elôzmények alapján, IBM SPSS Statistics 25 programmal készültek. A szerhasználó magatartásokkal kapcsolatos prevalenciváltozók képzése az EMCDDA (2002) standardoknak megfelelóen, az életprevalencia (lifetime prevalence, továbbiakban: LTP), az éves prevalencia (last year prevalence, továbbiakban: LYP), illetve a havi prevalencia (last month prevalence, továbbiakban: LMP) kiszámítása során ún. „konzisztencia korrekció” (i. m. 35.) alkalmazásával történt.

2. táblázat. Az OLAAP 2015 kutatás módszertani jellemzőinek összefoglalása

\begin{tabular}{l|l}
\hline Az adatfelvétel ideje & 2015. március-április \\
\hline Területi lefedettség & Országos \\
\hline Célpopuláció & 18-64 éves magyarországi lakónépesség \\
\hline Mintakeret & $\begin{array}{l}\text { A KEKKH 2014. január 1-i nyilvántartása szerint érvényes lakcímmel } \\
\text { rendelkezó állandó lakosság (6 583 433 fó) }\end{array}$ \\
\hline Mintaválasztás módja & $\begin{array}{l}\text { Régió, településméret, életkor szerint rétegzett véletlen minta, } \\
\text { a 18-34 éves korosztály felülreprezentálásával (oversampling) }\end{array}$ \\
\hline Mintanagyság & Teljes minta: Br: 2477 fó / N: 2274 fó \\
\hline Elméleti hibahatár & Az almintákban 95\%-os megbízhatósági szinten $\pm 2,5 \%{ }^{3}$ \\
\hline Adatgyújtési eljárás & Kevert: személyes kérdezés (face to face) + önkitöltôs technika \\
\hline Adatfelvétel eszköze & $\begin{array}{l}\text { EMQ + ÚPSZ + viselkedési addikciók + pszichiátriai tünetek + attitú- } \\
\text { dök + szociodemográfiai kérdések }\end{array}$ \\
\hline Súlyozás & $\begin{array}{l}\text { A felülreprezentáció és a mintakiesések miatti torzulások korrigálá- } \\
\text { sára rétegkategóriák szerinti mátrixsúlyozás. } \\
18-64 \text { éves súlyozott minta nagysága: } 1490 \text { fó } \\
18-34 \text { éves súlyozott minta nagysága: 1534 fó }\end{array}$ \\
\hline
\end{tabular}

Az elméleti hibahatár számítása során ún. konzervatív megoldásként az 1490 fôs súlyozott mintából indultunk ki. Tekintettel arra, hogy a 18-34 éves populációban alkalmazott felülreprezentálás (oversampling) miatt nem elemszámtartó súlyozást alkalmaztunk, a kutatás során ténylegesen elért személyek száma nagyobb, az ahhoz tartozó elméleti hibahatár pedig kisebb $( \pm 2,055)$ a súlyozott mintára számított értéknél. 


\section{EREDMÉNYEK}

\section{Prevalenciaértékek}

A kutatás eredményei szerint a magyarországi 18-64 éves népességben minden tízedik válaszoló fogyasztott már valamilyen a tiltott drogot ${ }^{4}$ az élete során (3. táblázat). Az éves prevalencia értéke 2,3\%. A valaha használók közel egynegyede használt az elmúlt évben (is) valamilyen tiltott szert, s többségük (közel háromnegyedük) tényleges folyamatos használó. A tiltott drogok havi prevalenciaértéke alapján a valaha fogyasztókon belül kb. minden nyolcadik használó aktuálisan (is) használ valamilyen tiltott szert.

A 18-64 éves népességben kapott értékekhez képest a fiatal felnôtt (18-34 éves) népességben - a drogfogyasztás növekvô társadalmi trendje, illetve a drogok kipróbálásának és használatának korosztályos jellege következtében (lásd késôbb drogfogyasztás kumulált prevalencia görbéjét) - a drogfogyasztás különbözô idôszakra számított prevalenciaértékei 95\%-os megbízhatósággal rendre hibahatáron túl magasabbak: a tiltott drogok életprevalencia-értéke 17,7\%, az éves prevalencia értéke 5,3\%, a havi prevalencia pedig 2,8\%. A valaha használó fiatal felnôttek megközelítóleg egyharmada az elmúlt évben (is) fogyasztott valamilyen tiltott szert, kb. egyhatoduk pedig aktuálisan (is) használ (3. táblázat).

A felnôtt népességben a legtöbben marihuánát/hasist fogyasztottak eddig életük során (hibahatár: $\pm 1,4$ ), közel fele ekkora, de a többi szerhez képest kimagasló az ecstasy (hibahatár: $\pm 1,0$ ) életprevalencia-értéke. E két legnépszerúbb szert - azoktól jelentôsen elmaradva, hibahatáron belül megegyezó életprevalencia-értékekkel - követik a szintetikus kannabinoidok (hibahatár: $\pm 0,7$ ), az amfetamin (hibahatár: $\pm 0,7$ ) és az új stimulánsok (hibahatár: $\pm 0,6$ ). A fiatal felnôtt népességben a szerenkénti életprevalencia-értékek alapján kirajzolódó szerpreferenciák - a legnépszerúbb szerek esetében - a felnôtt lakosságban tapasztalt sorrenddel megegyezőek, csak az életprevalencia-értékek mintegy kétszer nagyobbak (1. ábra).

3. táblázat. A tiltott drogok elterjedtségének fớbb mutatói (18-34 és 18-64 éves válaszolók százalékában, a 95\%-os megbízhatósági szinten érvényes standard hiba (SE) feltüntetésével)

\begin{tabular}{|l|r|r|r|r|r|r|}
\hline \multirow{2}{*}{ Fóbb mutatók } & \multicolumn{3}{|c|}{$18-64$ évesek } & \multicolumn{3}{c|}{$18-34$ évesek } \\
\cline { 2 - 7 } & \multicolumn{1}{|c|}{$\mathrm{N}$} & \multicolumn{1}{c|}{ SE } & \multicolumn{1}{c|}{$\mathrm{N}$} & \multicolumn{1}{c|}{$\%$} & \multicolumn{1}{c|}{$\mathrm{SE}$} \\
\hline Életprevalencia - LTP & 1341 & 9,9 & $\pm 1,6$ & 1397 & 17,7 & $\pm 2,0$ \\
\hline Éves prevalencia - LYP & 1338 & 2,3 & $\pm 0,8$ & 1392 & 5,3 & $\pm 1,2$ \\
\hline Havi prevalencia - LMP & 1343 & 1,2 & $\pm 0,6$ & 1394 & 2,8 & $\pm 0,9$ \\
\hline Folyamatos fogyasztási ráta & 129 & 24,0 & $\pm 7,4$ & 239 & 30,7 & $\pm 5,9$ \\
\hline Új belépók aránya & 129 & 6,4 & 4,2 & 239 & 9,2 & 3,7 \\
\hline Kilépési arány & 129 & 76,0 & 7,4 & 239 & 69,3 & 5,9 \\
\hline Folyamatos fogyasztási ráta incidencia nélkül & 129 & 17,6 & $\pm 6,6$ & 239 & 21,5 & $\pm 5,2$ \\
\hline
\end{tabular}

A kutatás az alábbi tiltott drogokat vizsgálta: marihuána/hasis, szintetikus kannabisz, ecstasy, amfetamin, kokain, crack, új stimulánsok, heroin, egyéb opiátok, LSD, mágikus gomba, GHB, mefedron, intravénás drog, más drog. 


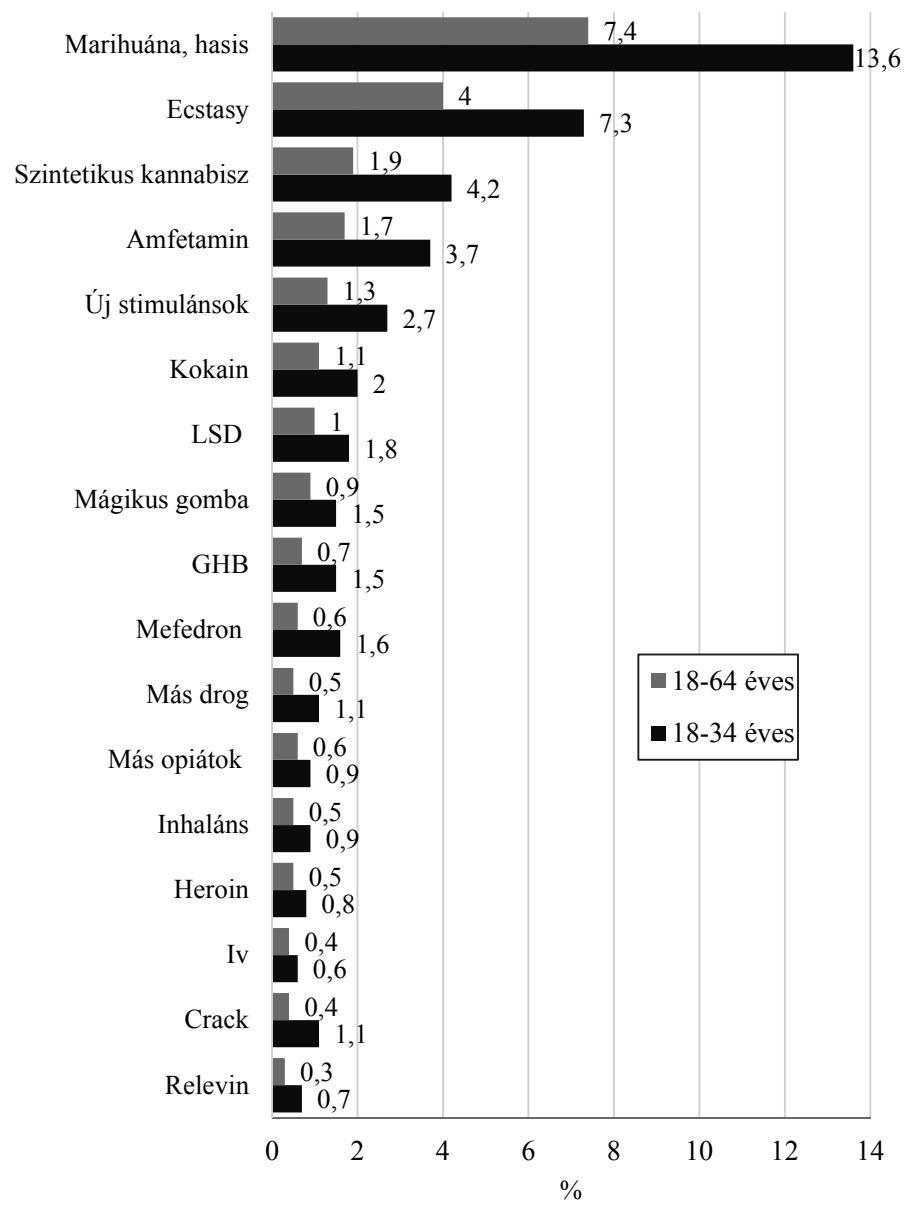

1. ábra. A szerenkénti életprevalencia-értékek (18-64 éves és 18-34 éves válaszolók százalékában $)^{5}$

\section{Polidroghasználat}

A 18-64 éves népességben az elmúlt évben használók kétharmada a kutatás során vizsgált 14-féle drog közül mindössze egy- vagy kétféle drogot használt a kutatást megelôzó év során. ${ }^{6}$ A másik egyharmad $(34,6 \%)$ fogyasztási mintázata változatosabb: ốk

A dummy drog esetében az életprevalencia a 18-64 éves válaszolók körében 0,3\%, a 18-34 éves válaszolók körében pedig $0,7 \%$.

6 Ha csak az EMQ standard 6-féle drogra (cannabis, XTC, amfetamin, kokain, heroin, LSD) (EMCDDA, 2002) vizsgáljuk a polidroghasználat elôfordulását, akkor a kétharmad (65,2\%) mindössze 1-féle drogot használt, 2-féle drogot használók aránya pedig 18,6\% a 18-64 éves népességben. 


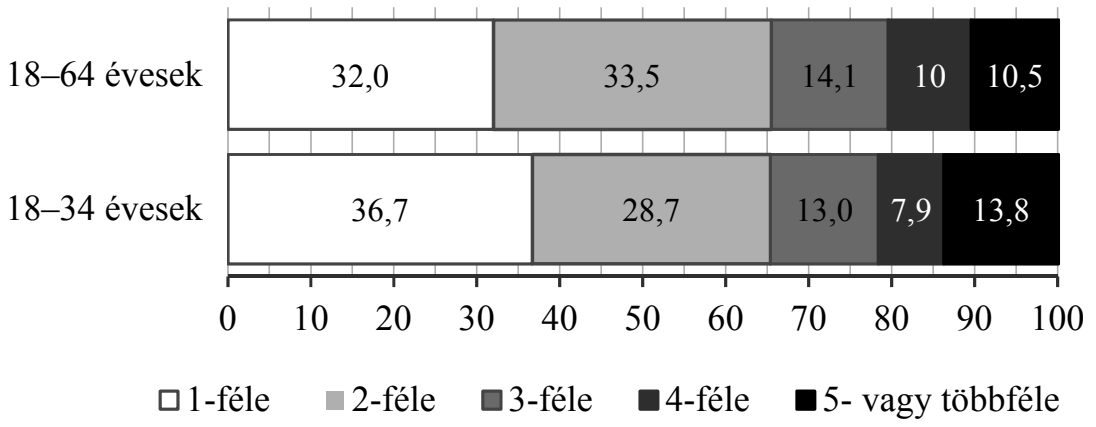

2. ábra. Polidroghasználat (a vizsgált 14-féle drogra), az elmúlt évben használó 18-64 évesek $(\mathrm{N}=31)$ és 18-34 évesek ( $\mathrm{N}=73)$ százalékában

legalább háromféle, ezen belül 10,5\% öt- vagy többféle drogot fogyasztott. A fiatal felnôtt népesség fogyasztási mintázatának változatossága - a mérés hibahatárát figyelembe véve - nem különbözik a felnôtt népességben általában tapasztalttól (2. ábra).

\section{Elsố droghasználat}

Az elsố droghasználat átlagos életkora a 18-64 éves populációban a 20 éves kor (módusz szintén 20, medián 19), s 17 évesen egynegyedük (25,5\%), 16 éves korban pedig egytizedük $(10,8 \%)$ volt túl volt az elsố használaton. Az elsô droghasználat életkorának csökkenô társadalmi tendenciáját jelzi, hogy a fiatal felnôtt válaszolók körében a tiltott droggal való elsố találkozás korábban, átlagosan 18-19 éves kor között (18,6 évesen), leggyakrabban (módusz) pedig 17 évesen történt. A valaha használó fiatal felnôttek fele 18 évesen (medián), több mint egyharmaduk (36\%) 17 évesen, minden hatodik használó $(15,7 \%)$ pedig 16 éves korban volt túl az elsố használaton.

A 18-64 éves és a 18-34 éves népességre - az elsô drogfogyasztás életkora alapján számított - kumulált prevalenciagörbék ${ }^{7}$ egymáshoz viszonyított helyzete pedig azt is jelzi (3. ábra), hogy a fiatal felnôtt populációban - az elsố használat életkorának alacsonyabb átlagértéke mellett - nem jelent meg korábban a drogokkal való ismerkedés, azonban az egyes korévekben jóval nagyobb volt a kockázata a drogokkal való kapcsolatba kerülésnek. A vizsgálat idején 18-34 éves korosztály tagjai a legnagyobb kockázatnak 16-18 éves koruk között voltak kitéve: ekkor évente a korosztály mintegy 3\%-a próbált ki valamilyen tiltott drogot. Majd 18-20 éves kor között ez a kockázat 2\%-ra, 20-27 éves kor között pedig átlagosan kevesebb mint fél százalékra csökkent, s aki 27 éves koráig nem került kapcsolatba a drogokkal, az késôbb már nem próbálta ki.

Amennyiben valamely populációban az elsô droghasználat évére vonatkozó gyakorisági adatok kumulált értékeit ábrázoljuk, a görbék meredeksége a populáció drogokkal való kapcsolatba kerülésének, azaz az életprevalencia-érték növekedésének kockázatát mutatja a különbözô életkorokban. 


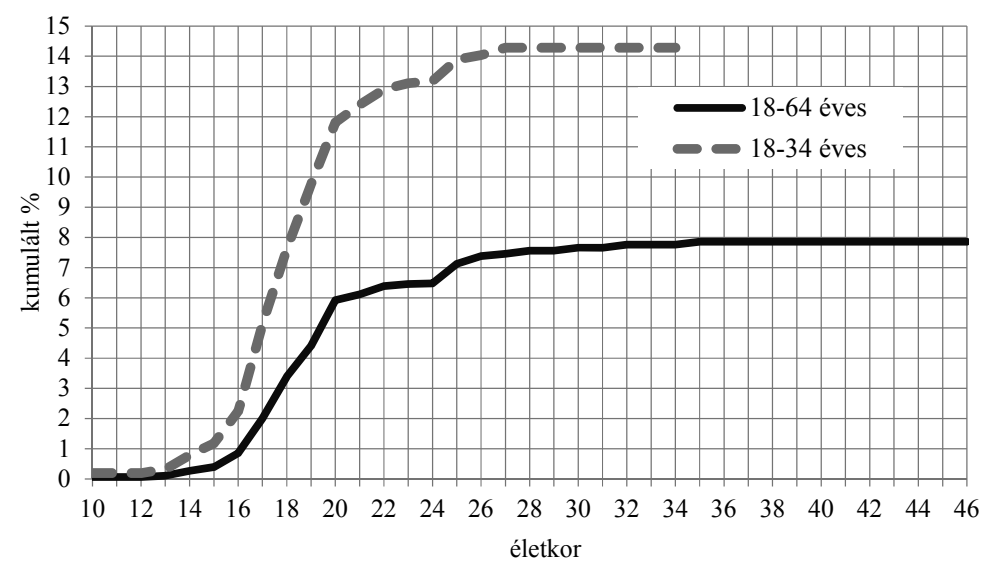

3. ábra. A tiltott drogfogyasztás kumulált prevalenciagörbéje a 18-64 éves $(\mathrm{N}=1349)$ és a 18-34 éves $(\mathrm{N}=1399)$ válaszolók körében

A 18-64 éves korosztályban is a 16-20 éves kor közötti periódus volt a legnagyobb kitettségú életszakasz, azonban egyik korévben sem haladta meg a kockázat az 1,5\%-ot.

A kumulált prevalenciagörbe nemcsak a drogokkal való kapcsolatba kerülés kockázatának korosztályos jellegét mutatja meg, hanem a különböző korosztályokra vonatkozó görbék egymáshoz viszonyított helyzete lehetôséget ad a keresztmetszeti adatok alapján a droghasználat társadalmi tendenciáinak becslésére is: a 18-64 éves népességhez képest a fiatal felnôttek kumulált görbéjének nagyobb meredeksége a drogfogyasztás hosszú távon növekvő tendenciáját is jelezi.

\section{Észlelt fogyasztás, észlelt hozzáférhetôség, fogyasztásnak való kitettség percepciója}

Egy társadalomban a különbözô szerhasználó magatartások elterjedtségének, a társadalom szerhasználati prioritásainak megismeréséhez - különösen, ha a szerhasználat bevallása nagy vagy szerenként változó társadalmi és törvényi kockázatokat hordoz fontos információkkal szolgálhatnak a fogyasztási adatoknál kevésbé érzékeny, a drogjelenség percepciójával kapcsolatos adatok. Ilyen a környezetben észlelt fogyasztás, a drogok beszerezhetôségével kapcsolatos vélekedések (észlelt hozzáférés), valamint a fogyasztásnak való kitettségre vonatkozó percepciók.

A fogyasztásnak való kitettség alapján a legnépszerúbb szerek vonatkozásában kirajzolódó szersorrend gyakorlatilag leképezi az életprevalencia-adatok alapján azonosítható szerpreferenciákat. Az észlelt hozzáférés alapján is csak egy esetben tapasztalunk eltérést: az LSD kétharmados biztonsággal megelôzi - az életprevalencia alapján a fogyasztásban azonos súllyal szereplô - a kokaint. Az észlelt fogyasztási adatok szintén döntôen megerôsítik a prevalenciaadatokban jelentkezô szerhasználati prioritásokat: az egyetlen eltérés, hogy prevalenciaadatok alapján kirajzolódó szersorrendhez képest a környezetében jelenlévô fogyasztására vonatkozó lakossági percepciók alapján az új stimulánsok relatíve kisebb jelentôséggel bírnak (4. ábra). 
A drogjelenség percepciójával kapcsolatos információk tehát a saját fogyasztással kapcsolatos bevallások eredményeihez rendre hasonló tendenciákat jeleznek, megerôsítve azt, hogy a magyar társadalomban a legelterjedtebb drog a marihuána, ezt követi az ecstasy, majd a szintetikus kannabisz, illetve az amfetamin. A legtöbb jelzés (saját fogyasztás bevallása, észlelt hozzáférés, fogyasztásnak való kitettség) alapján az amfetamint az új stimulánsok követik, de ezt a saját környezetében relatíve kevésbé érzékeli a lakosság.

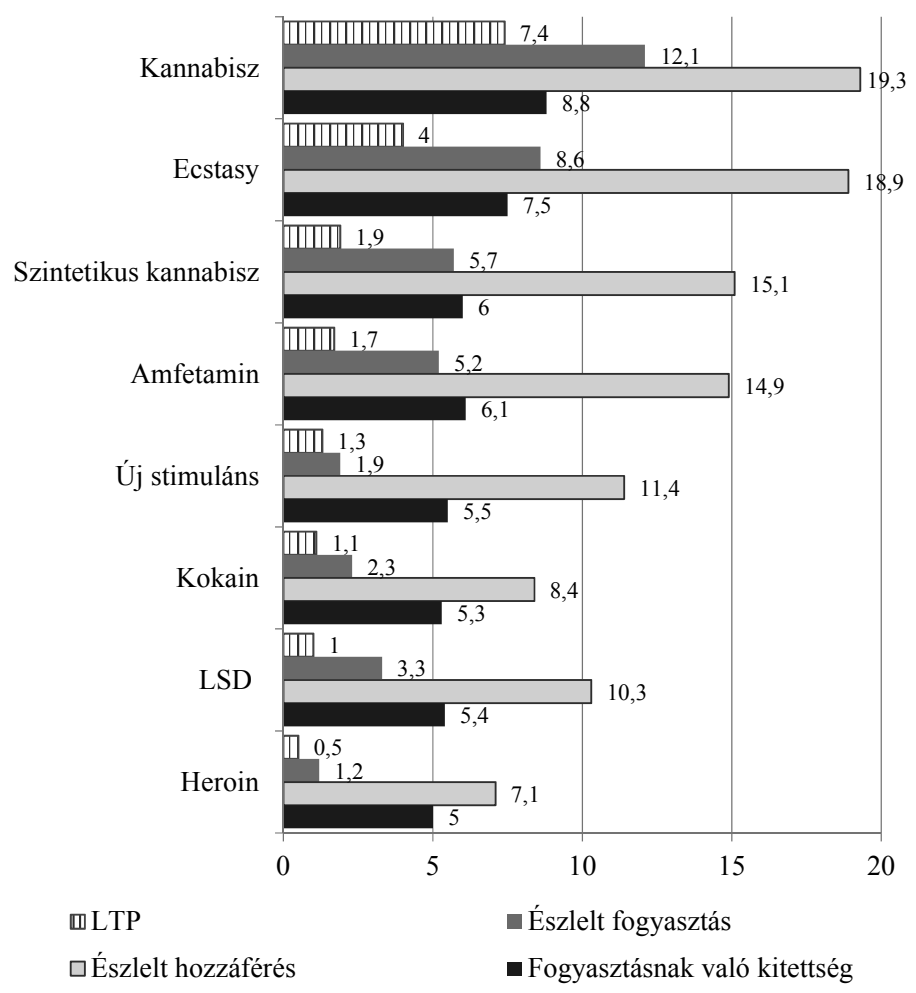

4. ábra. A fogyasztásnak való kitettség, ${ }^{8}$ az észlelt fogyasztás, ${ }^{9}$ észlelt hozzáférés, ${ }^{10}$ valamint az életprevalencia (LTP) alakulása a 18-64 éves populációban (\%)

8 Az „Elôfordult-e az elmúlt 12 hónapban, hogy az alábbi drogok valamelyikével kínálták (ingyenesen vagy azért, hogy vásároljon)?” - kérdésre adott „legalább egyszer” válaszok aránya, a válaszolók $\%$-ában.

9 A „Van-e az ön ismerôsei között olyan személy, aki az alábbi szerek valamelyikét valaha fogyasztotta?” - kérdésre adott „igen” válaszok aránya, a válaszolók \%-ában.

10 A „Mit gondol, mennyire nehezen tudná beszerezni a következô drogokat 24 órán belül” - kérdésre adott „elég könnyen” vagy „nagyon könnyen” válaszok aránya, a válaszolók \%-ában. 


\section{A droghasználat szociodemográfiai és pszichológiai mintázódása}

A tiltottdrog-használatban való érintettség társadalmi-demográfiai mintázódását leíró statisztikai eszközökkel elemezve, a vizsgált indikátorok mentén többnyire szignifikáns $(\mathrm{p}<0,05)$ vagy tendencia jellegú ( $\mathrm{p}>0,05$ és $\mathrm{p}<0,1)$ eltérések figyelhetôk meg (lásd 4-5. táblázat).

Leginkább markáns különbségek az életkor vonatkozásában tapasztalhatók: a legfiatalabb (18-24 éves) felnôtt népesség körében a tiltottdrog-használat életprevalencia-értéke több mint hétszerese a legidôsebb (55-64 éves) korosztályban mért értéknek, s a valaha tiltott drogokkal kapcsolatba került népesség átlagosan mintegy 9 ével fiatalabb azoknál, akik soha nem használtak semmilyen tiltott szert. A tiltottdrog-használat urbanizációs mintázata szintén markánsan megmutatkozik: az 50 ezer fốs vagy nagyobb településen élók körében több mint kétszeres életprevalencia-értékeket mértünk, mint a kisebb településeken, s hasonló különbség jelentkezik fôváros-vidék viszonylatban is. A leíró statisztikai adatok alapján a férfiak életprevalencia-értéke is szignifikánsan meghaladja a nôkét.

Jelentôs különbségek azonosíthatók a családi minta tekintetében is: a szúk vagy tág családban előforduló deviáns magatartások száma esetében a hatásméret megközelíti az életkori hatás nagyságát.

A kulturális, illetve a gazdasági státus vizsgált indikátorainak többsége mentén szintén szignifikáns mintázódást tapasztaltunk. Az iskolai végzettség, a munkaerô-piaci aktivitás, a háztartás jövedelme, illetve relatív anyagi helyzete alapján a kedvezóbb státusúak mutatnak az átlagosnál nagyobb kitettséget, s tendencia jelleggel kisebb a droghasználók deprivációs indexe is. Más státusmutatók (szakképzettség, végzettségi mobilitás, szubjektív anyagi helyzet, anyagiakkal vagy munkával való elégedettség) ugyanakkor nem jeleztek szignifikáns mintázódásokat.

A társadalmi integrációval kapcsolatos magyarázatok közül leginkább a vallás megóvó szerepe azonosítható: a nem vallásos válaszolók körében kapott életprevalencia-érték kétszer nagyobb, mint a - maga módján vallásos vagy az egyház tanításait követô vallásos népességben. Tendencia jelleggel alacsonyabb a droghasználók társas (családi és egyéb társas) kapcsolatokkal való elégedettsége is, azonban a családi integráció objektív indikátorai (háztartásméret, együtt élố kapcsolat léte) mentén nem mutatkozott szignifikáns különbség. A leíró statisztikai eredmények hasonlóképpen nem jeleztek eltérést a droghasználati tapasztalattal rendelkezô, illetve nem rendelkezô válaszolók anómikus érzületeiben és általános jóllétében sem.

A droghasználat az Impulzivitás skála (BIS-11) összpontszámával és az alskálák többségével is szignifikáns összefüggést mutat: a fogyasztók körében - a tervezés hiánya alskála kivételével - mindegyik skála átlagértéke szignifikánsan magasabb. A pszichiátriai tünetek vizsgálatára alkalmazott Rövid Tünetlista (BSI) esetében azonban sem az összpontszám, sem az alskálák tekintetében nem jelentkezett szignifikáns mintázódás: mindössze az ellenségesség alskála mentén kaptunk szignifikánsan magasabb átlagértéket a fogyasztók esetében.

A 4. és 5. táblázatban szereplô, a leíró statisztikai elemzések során használt változók teljes körén bináris logisztikus regressziós elemzéssel megvizsgáltuk, hogy a többi változó kontroll alatt tartása mellett mely társadalmi-demográfiai, illetve pszichológiai 
4. táblázat. A tiltottdrog-használat életprevalencia-értéke a különbözố szociodemográfiai jellemzốk mentén a 18-64 éves népességben (a válaszolók százalékában)

\begin{tabular}{|c|c|c|c|c|c|}
\hline & Teljes N & Használó N & LTP $(\%)$ & $\chi^{2}(\mathrm{df})$ & $\mathrm{p}$ \\
\hline \multicolumn{6}{|l|}{ Nem } \\
\hline Férfi & 603 & 73 & 12,1 & \multirow{2}{*}{$5,87(1)$} & \multirow{2}{*}{0,015} \\
\hline Nő & 738 & 60 & 8,1 & & \\
\hline \multicolumn{6}{|l|}{ Korcsoport } \\
\hline $18-24(170)$ & 170 & 33 & 19,4 & \multirow{5}{*}{$59,08(4)$} & \multirow{5}{*}{$<0,001$} \\
\hline $25-34(277)$ & 277 & 46 & 16,6 & & \\
\hline $35-44(340)$ & 340 & 35 & 10,3 & & \\
\hline $45-54(262)$ & 262 & 10 & 3,8 & & \\
\hline $55-64(291)$ & 291 & 8 & 2,7 & & \\
\hline \multicolumn{6}{|l|}{ Településméret } \\
\hline$<50000$ lakos & 855 & 64 & 7,5 & \multirow{2}{*}{$15,52(1)$} & \multirow{2}{*}{$<0,001$} \\
\hline$\geq 50000$ lakos & 487 & 69 & 14,2 & & \\
\hline \multicolumn{6}{|l|}{ Vidék-fôváros } \\
\hline vidék & 1099 & 95 & 8,6 & \multirow{2}{*}{$10,90(1)$} & \multirow{2}{*}{0,001} \\
\hline fôváros & 243 & 38 & 15,6 & & \\
\hline \multicolumn{6}{|c|}{ Várható legmagasabb iskolai végzettség } \\
\hline 8 általános vagy kevesebb & 199 & 14 & 7 & \multirow{5}{*}{$10,46(4)$} & \multirow{5}{*}{0,033} \\
\hline szakmunkás & 368 & 27 & 7,3 & & \\
\hline érettségi & 518 & 58 & 11,2 & & \\
\hline fốiskola/BA/BSC & 192 & 23 & 12 & & \\
\hline egyetem/MA/MSC & 63 & 11 & 17,5 & & \\
\hline \multicolumn{6}{|l|}{ Szakképzettség } \\
\hline nincs & 277 & 29 & 10,5 & \multirow{2}{*}{$0,16(1)$} & \multirow{2}{*}{0,690} \\
\hline van & 932 & 90 & 9,7 & & \\
\hline \multicolumn{6}{|l|}{ Végzettségi mobilitás } \\
\hline felfelé mobil & 725 & 61 & 8,4 & \multirow{3}{*}{$3,84(2)$} & \multirow{3}{*}{0,146} \\
\hline nem mobil & 503 & 59 & 11,7 & & \\
\hline lefelé mobil & 109 & 12 & 11 & & \\
\hline \multicolumn{6}{|l|}{ Munkaerô piaci aktivitás } \\
\hline nincs keresố tevékenysége & 470 & 33 & 7 & \multirow{2}{*}{$6,66(1)$} & \multirow{2}{*}{0,010} \\
\hline van keresố tevékenysége & 866 & 99 & 11,4 & & \\
\hline \multicolumn{6}{|c|}{ Háztartás nettó havi jövedelme } \\
\hline$<100000 \mathrm{Ft}$ & 154 & 12 & 7,8 & & \\
\hline $101000-200000 \mathrm{Ft}$ & 370 & 26 & 7 & $1996(3)$ & 0005 \\
\hline $200001-400000 \mathrm{Ft}$ & 444 & 53 & 11,9 & & 0,005 \\
\hline $400000 \mathrm{Ft}$ felett & 60 & 12 & 20 & & \\
\hline A háztartás szubjektív anya & elyzete & & & & \\
\hline kényelmesen megélnek & 85 & 12 & 14,1 & & \\
\hline kijönnek a jövedelmükból & 692 & 74 & 10,7 & & 0215 \\
\hline nehezen élnek & 394 & 35 & 8,9 & $3,55(3)$ & 0,315 \\
\hline nagyon nehezen élnek & 147 & 11 & 7,5 & & \\
\hline
\end{tabular}


4. táblázat folyt.

\begin{tabular}{|c|c|c|c|c|c|}
\hline & Teljes N & Használó N & LTP $(\%)$ & $\chi^{2}(\mathrm{df})$ & $\mathrm{p}$ \\
\hline \multicolumn{6}{|c|}{ A háztartás relatív anyagi helyzete a kérdezett percepciója alapján } \\
\hline $\begin{array}{l}\text { magasan a legjobbak között } \\
\text { van }\end{array}$ & 8 & 3 & 37,5 & \multirow{7}{*}{$26,37(6)$} & \multirow{7}{*}{$<0,001$} \\
\hline sokkal jobb az átlagnál & 38 & 8 & 21,1 & & \\
\hline valamivel jobb az átlagnál & 191 & 30 & 15,7 & & \\
\hline átlagos & 760 & 67 & 8,8 & & \\
\hline $\begin{array}{l}\text { valamelyest rosszabb az } \\
\text { átlagnál }\end{array}$ & 193 & 11 & 5,7 & & \\
\hline sokkal rosszabb az átlagnál & 92 & 6 & 6,5 & & \\
\hline legrosszabbak között van & 41 & 6 & 14,6 & & \\
\hline \multicolumn{6}{|l|}{ Vallásosság } \\
\hline $\begin{array}{l}\text { vallásos, az egyház tanításait } \\
\text { követi }\end{array}$ & 130 & 11 & 8,5 & \multirow{4}{*}{$16,89(3)$} & \multirow{4}{*}{0,001} \\
\hline vallásos a maga módján & 638 & 43 & 6,7 & & \\
\hline nem tudja, hogy vallásos-e & 120 & 14 & 11,7 & & \\
\hline nem vallásos & 438 & 62 & 14,2 & & \\
\hline \multicolumn{6}{|l|}{ Partnerkapcsolat } \\
\hline egyedül él & 321 & 37 & 11,5 & \multirow{2}{*}{$1,26(1)$} & \multirow{2}{*}{0,261} \\
\hline kapcsolatban él & 1013 & 95 & 9,4 & & \\
\hline
\end{tabular}

Megjegyzés: $\mathrm{N}$ = elemszám; LTP = életprevalencia; $\mathrm{df}=$ szabadságfok; $\mathrm{p}=$ szignifikancia

5. táblázat. Különbözô szociodemográfiai változók, valamint az impulzivitásskála (BIS) és a Rövid tünetlista (BSI) összpontszámának és alskáláinak átlagértéke a valamilyen tiltott drogot életük során használók és nem használók körében a 18-64 éves népességben

\begin{tabular}{l|c|c|c|c|c|c|c|c|c|c|c}
\hline \multirow{2}{*}{ Változó } & \multicolumn{3}{|c|}{ Nem fogyasztott } & \multicolumn{3}{|c|}{ Fogyasztott } & t érték & $\mathrm{df}$ & $\mathrm{p}$ & $\mathrm{d}$ \\
\cline { 2 - 12 } & $\mathrm{N}$ & Átlag* & Szórás & $\mathrm{N}$ & Átlag* & Szórás & & & & \\
\hline Életkor & 1209 & 42,32 & 13,12 & 133 & 33,20 & 10,61 & 9,15 & 179,02 & $<0,001$ & 0,71 \\
\hline Háztartásméret & 1202 & 3,07 & 1,41 & 132 & 3,05 & 1,46 & 0,14 & 1333 & 0,884 & \\
\hline $\begin{array}{l}\text { Családi } \\
\text { devianciák száma }\end{array}$ & 1158 & 1,69 & 1,42 & 131 & 2,63 & 1,90 & $-5,46$ & 146,82 & $<0,001$ & 0,64 \\
\hline $\begin{array}{l}\text { Anómia } \\
\text { összpontszám }\end{array}$ & 1075 & 13,05 & 6,56 & 123 & 13,36 & 6,49 & $-0,50$ & 1196 & 0,619 & \\
\hline $\begin{array}{l}\text { Deprivációs } \\
\text { index }\end{array}$ & 1209 & 4,95 & 4,60 & 133 & 4,22 & 4,34 & 1,76 & 1339 & 0,080 & \\
\hline $\begin{array}{l}\text { Munkavégzéssel } \\
\text { töltött órák } \\
\text { száma/hét }\end{array}$ & 1184 & 25,65 & 20,80 & 131 & 30,11 & 19,20 & $-2,51$ & 166,32 & 0,013 & 0,22 \\
\hline $\begin{array}{l}\text { Elégedettség: } \\
\text { a munkájával }\end{array}$ & 1138 & 3,47 & 1,26 & 128 & 3,35 & 1,28 & 1,09 & 1265 & 0,276 & \\
\hline $\begin{array}{l}\text { Elégedettség: } \\
\text { anyagi } \\
\text { körülményeivel }\end{array}$ & 1193 & 2,90 & 1,21 & 131 & 2,90 & 1,25 & $-0,05$ & 1322 & 0,960 & \\
\hline
\end{tabular}


5. táblázat folyt.

\begin{tabular}{|c|c|c|c|c|c|c|c|c|c|c|}
\hline \multirow{2}{*}{ Változó } & \multicolumn{3}{|c|}{ Nem fogyasztott } & \multicolumn{3}{|c|}{ Fogyasztott } & \multirow[t]{2}{*}{ t érték } & \multirow[t]{2}{*}{$\mathrm{df}$} & \multirow[t]{2}{*}{$\mathrm{p}$} & \multirow[t]{2}{*}{$d$} \\
\hline & $\mathrm{N}$ & Átlag* & Szórás & $\mathrm{N}$ & Átlag* & Szórás & & & & \\
\hline $\begin{array}{l}\text { Elégedettség: } \\
\text { családi } \\
\text { kapcsolataival }\end{array}$ & 1193 & 4,10 & 1,03 & 131 & 3,92 & 1,09 & 1,83 & 1323 & 0,068 & \\
\hline $\begin{array}{l}\text { Elégedettség: } \\
\text { párkapcsolatával }\end{array}$ & 1167 & 3,86 & 1,36 & 129 & 3,75 & 1,38 & 0,93 & 1294 & 0,352 & \\
\hline $\begin{array}{l}\text { Elégedettség: } \\
\text { egyéb társas } \\
\text { kapcsolataival }\end{array}$ & 1185 & 3,92 & 0,94 & 131 & 3,77 & 1,01 & 1,76 & 1313 & 0,078 & \\
\hline $\begin{array}{l}\text { Elégedettség: } \\
\text { egészségi } \\
\text { állapotával }\end{array}$ & 1192 & 3,75 & 1,07 & 131 & 3,94 & 0,99 & $-1,90$ & 1322 & 0,058 & \\
\hline $\begin{array}{l}\text { WHO általános } \\
\text { Jóllét skála }\end{array}$ & 1157 & 8,80 & 3,10 & 129 & 8,34 & 2,90 & 1,59 & 1284 & 0,111 & \\
\hline $\begin{array}{l}\text { Barratt } \\
\text { Impulzivitás } \\
\text { Skála (BIS-11) } \\
\text { Összpontszám } \\
\end{array}$ & 1068 & 34,13 & 7,47 & 120 & 36,28 & 8,23 & $-2,96$ & 1186 & 0,003 & 0,29 \\
\hline $\begin{array}{l}\text { BIS Tervezés } \\
\text { hiánya }\end{array}$ & 1090 & 14,16 & 4,12 & 122 & 14,60 & 4,55 & $-1,09$ & 1211 & 0,275 & \\
\hline $\begin{array}{l}\text { BIS Figyelmi } \\
\text { impulzivitás }\end{array}$ & 1103 & 9,52 & 2,82 & 124 & 10,37 & 2,89 & $-3,18$ & 1225 & 0,002 & 0,30 \\
\hline $\begin{array}{l}\text { BIS Motoros } \\
\text { impulzivitás }\end{array}$ & 1098 & 10,46 & 3,44 & 122 & 11,38 & 3,58 & $-2,80$ & 1218 & 0,005 & 0,27 \\
\hline $\begin{array}{l}\text { Rövid } \\
\text { Tünetlista (BSI) } \\
\text { Összpontszám }\end{array}$ & 1062 & 42,59 & 17,30 & 120 & 44,32 & 17,99 & $-1,04$ & 1180 & 0,300 & \\
\hline BSI Szorongás & 1085 & 9,51 & 4,03 & 121 & 9,93 & 4,26 & $-1,09$ & 1204 & 0,278 & \\
\hline BSI Depresszió & 1081 & 9,87 & 4,77 & 121 & 9,99 & 4,93 & $-0,26$ & 1201 & 0,796 & \\
\hline $\begin{array}{l}\text { BSI } \\
\text { Ellenségesség }\end{array}$ & 1082 & 7,51 & 3,21 & 121 & 8,16 & 3,69 & $-2,08$ & 1201 & 0,038 & 0,20 \\
\hline $\begin{array}{l}\text { BSI } \\
\text { Interperszonális } \\
\text { Érzékenység } \\
\end{array}$ & 1086 & 6,26 & 2,80 & 121 & 6,56 & 2,93 & $-1,13$ & 1206 & 0,259 & \\
\hline BSI Kényszer & 1088 & 9,80 & 4,41 & 121 & 9,70 & 4,13 & 0,25 & 1207 & 0,806 & \\
\hline
\end{tabular}

$\mathrm{N}$ = elemszám; $\mathrm{df}$ = szabadságfok; $\mathrm{p}$ = szignifikancia; $\mathrm{d}$ = Cohen d hatásméret mutató

Megjegyzés: A különbözô életdimenziókkal való elégedettség mérése ötfokozatú skálán történt, ahol az 1-es azt jelentette, hogy „egyáltalán nem elégedett” az 5-ös pedig hogy „teljes mértékben elégedett”. 
jellemzők gyakorolnak szignifikáns hatást a tiltottdrog-használat elôfordulására. Forward Stepwise (LR) módszerrel két szignifikáns $(\mathrm{p}<0,001)$, de a besorolás pontosságát a véletlenhez képest csak kismértékben javító modellt építettünk. ${ }^{11}$ Az elsô modellünk csak a társadalmi-demográfiai változókat tartalmazta, a második modellünk magyarázó változói közé pedig bevontuk a vizsgált pszichológiai háttérváltozókat is.

6. táblázat. A valamilyen tiltott drogot életük során használók becslésére a különbözô szociodemográfiai változókból épített bináris logisztikus regressziós modell

\begin{tabular}{|c|c|c|c|c|c|c|}
\hline \multirow{2}{*}{ Modellben maradt változók } & \multicolumn{3}{|c|}{ Modell 1} & \multicolumn{3}{|c|}{ Modell 2} \\
\hline & $\mathrm{p}$ & EH & $95 \% \mathrm{CI}$ & $\mathrm{p}$ & $\mathrm{EH}$ & $95 \% \mathrm{CI}$ \\
\hline Konstans & 0,035 & 0,06 & & 0,009 & 0,013 & \\
\hline Életkor & $<0,001$ & 0,93 & {$[0,90-0,96]$} & $<0,001$ & 0,093 & {$[0,91-0,96]$} \\
\hline \multicolumn{7}{|l|}{ Településméret } \\
\hline$\geq 50000$ & 0,007 & 2,22 & {$[1,25-3,98]$} & 0,002 & 2,54 & {$[1,40-4,62]$} \\
\hline$<50000$ & ref & & & & & \\
\hline \multicolumn{7}{|l|}{ Munkaerô piaci aktivitás } \\
\hline végez keresố tevékenységet & 0,001 & 4,54 & {$[1,924-10,73]$} & 0,001 & 4,56 & {$[1,83-11,36]$} \\
\hline $\begin{array}{l}\text { nem végez keresố tevékeny- } \\
\text { séget }\end{array}$ & ref & & & & & \\
\hline $\begin{array}{l}\text { A háztartás relatív anyagi hely- } \\
\text { zete a kérdezett percepciója } \\
\text { alapján }\end{array}$ & $<0,001$ & & & $<0,001$ & & \\
\hline $\begin{array}{l}\text { magasan a legjobbak között } \\
\text { van }\end{array}$ & 0,009 & 54,43 & {$[2,71-1095,42]$} & 0,009 & 71,37 & {$[2,92-1745,63]$} \\
\hline sokkal jobb az átlagnál & 0,006 & 23,67 & {$[2,48-226,15]$} & 0,008 & 37,03 & {$[2,61-526,35]$} \\
\hline valamivel jobb az átlagnál & 0,036 & 8,12 & {$[1,15-57,45]$} & 0,083 & 8,18 & {$[0,76-88,05]$} \\
\hline átlagos & 0,643 & 1,53 & {$[0,25-9,23]$} & 0,608 & 1,83 & {$[0,18-18,13]$} \\
\hline $\begin{array}{l}\text { valamelyest rosszabb az } \\
\text { átlagnál }\end{array}$ & 0,077 & 0,76 & {$[0,12-4,69]$} & 0,863 & 1,23 & {$[0,11-13,41]$} \\
\hline sokkal rosszabb az átlagnál & 0,765 & 0,75 & {$[0,11-4,94]$} & 0,741 & 1,51 & {$[0,13-17,25]$} \\
\hline legrosszabbak között van & ref & & & & & \\
\hline Vallásosság & 0,017 & & & & & \\
\hline $\begin{array}{l}\text { vallásos, az egyház tanításait } \\
\text { követi }\end{array}$ & 0,884 & 0,93 & {$[0,33-2,59]$} & & & \\
\hline vallásos a maga módján & 0,002 & 0,35 & {$[0,18-0,67]$} & & & \\
\hline nem tudja, hogy vallásos-e & 0,421 & 0,70 & {$[0,29-1,69]$} & & & \\
\hline nem vallásos & ref & & & & & \\
\hline Családi devianciák száma & $<0,001$ & 1,57 & {$[1,34-1,86]$} & $<0,001$ & 1,49 & {$[1,25-1,76]$} \\
\hline Anómia összpontszám & 0,025 & 1,07 & {$[1,01-1,14]$} & & & \\
\hline Elégedettség: a munkájával & 0,014 & 0,71 & {$[0,54-0,93]$} & 0,006 & 0,66 & {$[0,50-0,89]$} \\
\hline BIS összpontszám & $8<$ & 8 & $S$ & 0,017 & 1,05 & {$[1,01-1,10]$} \\
\hline
\end{tabular}

p = szignifikancia; $\mathrm{EH}$ = esélyhányados; $\mathrm{CI}$ = 95\%-os konfidencia-intervallum; ref = referencia kategória

11 A véletlen besorolás pontossága 89,4\%, ezen belül a droghasználók esetében $0 \%$. Az 1 . modellben ezek az arányok 90/20\%, a 2. modellben pedig 89,8/17\%. 
A 8 lépésben felépített elsô modellben - a többi változó kontroll alatt tartása mellett - meghatározó szerepet kap a kérdezetteknek a háztartás relatív anyagi helyzetére vonatkozó percepciója. A másokhoz képest a saját háztartásuk anyagi helyzetét a legrosszabbak közé tartozónak érzókhöz képest - ugyan magas konfidencia-intervallum mellett - a „magasan a legjobb körülmények között élők” körében a drogokkal való kapcsolatba kerülés esélye több mint ötvenszeres, az átalagnál „sokkal jobban élôké” pedig közel 24-szeres, de még az áltagosnál valamivel jobb körülmények esetén is 8-szoros kockázatot jelez a modellünk. Az inaktívakhoz képest a munkaerôpiac aktív szereplői körében négy és félszeres, az 50 ezer foonél nagyobb lélekszámú településeken pedig több mint kétszeres a drogfogyasztás kockázata. A családban elôforduló devianciák számának növekedésével másfélszeresére, a kérdezett anómikus érzületeinek intenzívebb jelenlétével pedig mérsékelten, de szignifikánsan emelkedik drogfogyasztás kipróbálásának az esélye. Ugyanakkor a többi változó hatásának kiszúrése mellett a nem vallásos válaszolókhoz képest közel egyharmada a drogfogyasztás előfordulásának az esélye a „maguk módján vallásosak” körében. ${ }^{12}$ Szintén megóvó tényezôként jelentkezik a munkával való nagyobb elégedettség, és az életkor növekedésével is szolidan, de szignifikánsan csökken annak az esélye, hogy valaki a droghasználati tapasztalattal rendelkezôk közé tartozzon.

Amennyiben az 1. modellben szereplô társadalmi-demográfiai magyarázó változókat kiegészítjük a vizsgált pszichológiai változókkal (10 db változó), akkor a 7 lépésben kapott modellben mindössze a BIS összpontszám kap szignifikáns szerepet: a BIS összpontszám növekedésével mérsékelten emelkedik a droghasználati tapasztalattal rendelkezôk csoportjába kerülés esélye. Sem a BIS alskálái, sem a BSI összpontszáma és alskálái a többi változó kontroll alatt tartása mellett nem jelenik meg. Ugyanakkor a BIS összpontszám modellbe kerülésével - az elsố modellben szignifikáns szerepet kapó - a vallás és az anómikus érzületek intenzitása változó elveszti a szerepét.

\section{A tiltott drogfogyasztás változása}

Magyarországon a 2015-ös vizsgálatot megelőzôen 2001-ben, 2003-ban és 2007-ben készültek országos reprezentatív mintán drogepidemiológiai vizsgálatok az általános populációban. A négy vizsgálat összehasonlítható populációját a 19-53 éves népesség jelenti, így a vizsgálatok által lefedett 14 év adatait ebben az életkori csoportban tudjuk vizsgálni. A korábbi - az ezeknél a vizsgálatoknál elvárt megbízhatósági és érvényességi mutatókkal rendelkezó - vizsgálatok adatai alapján azt mondhatjuk, hogy 2001 és 2003 között 95\%-os megbízhatósággal szignifikánsan növekedett a tiltott drogok életprevalencia-értéke, a 2003 és 2007 közötti idôszakban pedig - a fiatal populációkban tapasztalt változásokhoz hasonlóan (Elekes, 2009; Hibell és mtsai, 2009) - a prevalenciaértékekben stagnálás volt tapasztalható.

Amennyiben a 2001 és 2015 közötti tendenciákat vizsgáljuk, akkor - az egyes mérések konfidencia-intervallumát figyelembe véve - azt mondhatjuk, hogy a mért érté-

12 Itt jegyezzük meg, hogy a leíró elemzésekhez képest, a többi változó kontroll alatt tartása mellett az egyház tanításait követô vallásosság a modellben nem kapott szignifikáns szerepet. 
7. táblázat. A tiltott drogok kohorszelemzéssel korrigált életprevalencia-értéke 2015-ben (\%)

\begin{tabular}{|c|c|c|}
\hline & 2007 & 2015 \\
\hline Vizsgált kohorsz & $18-56$ & $26-64$ \\
\hline $\mathrm{N}$ & 2132 & 1150 \\
\hline Mért életprevalencia (SE) & $10,9 \%( \pm 1,3)^{13}$ & $8,3 \%( \pm 1,6)$ \\
\hline $\begin{array}{l}\text { Új belépók aránya az elmúlt } 8 \text { évben (LTP } \\
\text { \%-ában) }\end{array}$ & - & $18,3 \%$ \\
\hline Új belépôk nélküli életprevalencia (SE) & - & $8,3 * 81,7=6,8 \%^{14}( \pm 1,5)$ \\
\hline $\begin{array}{l}\text { Alulbecslés mértéke: [1-(új belépók nélküli } \\
\text { LTP 2015-ben/LTP 2007-ben)] }\end{array}$ & - & $1-(6,8 / 10,9)=0,38^{15}$ \\
\hline 18-53 éves korcsoportra mért LTP & $11,2 \%$ & $12,1 \%$ \\
\hline $\begin{array}{l}\text { 18-53 éves korcsoportra az alulbecslési arány- } \\
\text { nyal korrigált LTP }\end{array}$ & - & $12,1 / 0,62=19,5 \%^{16}$ \\
\hline
\end{tabular}

A korábbi adatok forrása: Paksi, 2009

kek alapján a magyarországi 18-53 éves felnôtt népességben a drogfogyasztás 2001 és 2003 között történt szignifikáns növekedését követôen 2003 óta a stagnálás jellemzó (5. ábra, világos szürke oszlopok).

Tekintettel arra, hogy - mint ahogy arra a módszertani eredmények bemutatásánál utaltunk - a 2015-ös OLAAP-kutatás módszertani jellemzói - a 2007-es vizsgálathoz képest - a mintavételen kívüli hibák fokozott jelenlétét jelezték, az adatok korábbi vizsgálatok kontextusában való értelmezése az átlagosnál nagyobb körültekintést igényel.

Amennyiben a 2015-ös és a 2007-es OLAAP-vizsgálat azonos időszakban (1950 és 1989 között) születettekre vonatkozó adatait egy kohorszvizsgálat egymást követô hullámaiként kezeljük, becslést fogalmazhatunk meg arra vonatkozóan, hogy a hibák szinten tartása mellett mekkora a tiltott drogok összesített életprevalencia-értékének minimálisan elvárható értéke 2015-ben (7. táblázat). ${ }^{17}$

13 A 18-56 éves korcsoportban 2007-ben 10,9\% volt a tiltott droghasználat életprevalencia-értéke, ami a mintavételen kívüli hibáknak a korábbi kutatásokkal azonos szinten tartása mellett, s azt feltételezve, hogy a korcsoportban nem történt új kipróbálás a két vizsgálat között eltelt 8 évben - egyben a drogfogyasztás 2015-ben minimálisan várható életprevalencia-értékét jelenti 2015-ben a 26-64 éves életkori csoportban.

14 A 2015-ös vizsgálatban a 26-64 éves korosztályban azonban a mért életprevalencia érték 8,3\%, s a valaha fogyasztók 18,3\%-a az elmúlt 8 évben használt elôször tiltott drogot. Ennek alapján a 2015-ös vizsgálatban mindössze $6,8 \%(8,3 \times 0,81,7)$ azok mért aránya, akik már 8 ével korábban is fogyasztottak. Az 1951 és 1989 között születettek kohorszát követve tehát a 2007-es 10,9\%-os élteprevalencia értékkel szemben 2015-ben 6,8\%-os mért értéket állíthatunk, ami 38\%-os alulbecslést jelent.

16 A 38\%-os alulbecslés alapján a 2015-ben mért érték a 2007-es értékbôl kiindulva kalkulálható fogyasztók arányának mindössze 62\%-át jelenti. Ezzel az aránnyal korrigálva a 2015-ben a 18-53 éves összehasonlító populációban mért 12,1\%-os LTP-t, kaptuk meg a táblázatban szereplô 19,5\%-os korrigált LTP értéket.

17 A becslés során abból indultunk ki, hogy egy születési kohorszot követve, az idô elôrehaladtával az kohorszban nem csökkenhet azok aránya, akik már kipróbáltak valamilyen magatartást. Ez a megállapítás nemcsak az egyéni szintû követéses vizsgálatokra érvényes, hanem különbözô idôpontokban a lakosság reprezentatív mintáján készült keresztmetszeti vizsgálatok adataira is. Következésképpen a 2007-es OLAAP-vizsgálat 18-56 éves, valamint a 2015-ös kutatás 26-64 éves korcsoportjaira vonatkozó adatokat egy kohorszvizsgálat egymást követố hullámaiként kezelhetjük. 


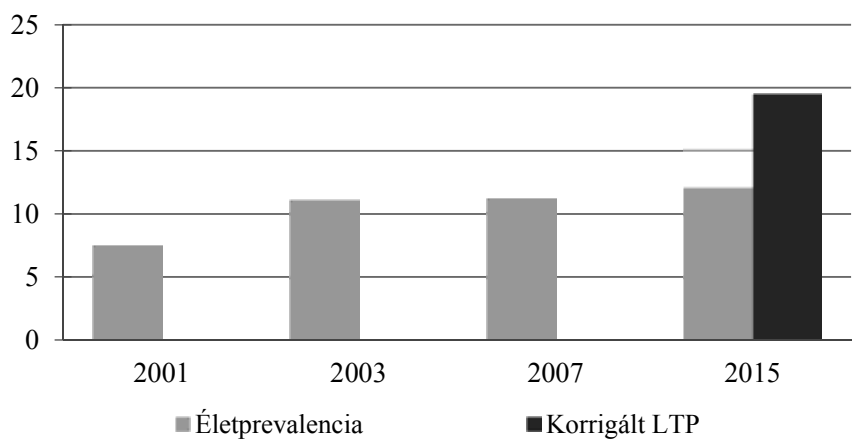

5. ábra. A tiltott drogfogyasztás főbb mutatóinak alakulása 2001 és 2015 között a 18-53 éves népességben $(\%)$

Korábbi adatok forrásai: Elekes és Paksi, 2004; Paksi, $2009^{15}$

A mért értékek alapján mutatkozó stagnálástól eltéróen a korrigált értékek az utóbbi 8 évben a tiltott drogfogyasztás elterjedtségének hibahatáron túli növekedésére engednek következtetni (5. ábra).

\section{ÖSSZEGZÉS, KÖVETKEZTETÉSEK}

Tanulmányunkban a magyarországi felnôtt népesség addiktológiai problémáinak feltérképezésére/nyomon követésére nyolc év kihagyás után elkészült 2015-ös Országos Lakossági Adatfelvétel Addiktológiai Problémákról (OLAAP 2015) címú vizsgálat drogfogyasztással kapcsolatos eredményeit mutattuk be.

A kutatás eredményei szerint a magyarországi 18-64 éves népességben minden tízedik válaszoló fogyasztott már valamilyen a tiltott drogot az élete során. A tiltott drogok éves prevalenciaértéke 2,3\%, a havi prevalenciaértéke pedig 1,2\%. Amennyiben a 2007 és 2015 közötti változásokat vizsgáljuk, akkor a mért értékek alapján azt mondhatjuk, hogy a felnôtt népességben a drogfogyasztási tapasztalattal rendelkezô populáció stagnálása volt jellemzó. Mivel azonban a 2015-ös OLAAP-kutatás módszertani jellemzői a mintavételen kívüli hibák fokozott jelenlét jelezték, a változások értelmezéséhez - egy korábbi tanulmányunkban (Paksi és mtsai, 2018) - egy kohorszelemzésen

A tiltott drogok kohorszelemzéssel korrigált életprevalencia-értékére vonatkozó eljárást és a számítások részletes leírását bemutatjuk egy, az önbevallásos addiktolgóiai vizsgálatok változó módszertani jellemzôinek utólagos kezelésével foglalkozó írásunkban (Paksi, Demetrovics, Griffiths, Magi és Felvinczi, 2018).

15 Itt jegyezzük meg, hogy a 2001 és 2003 között mért adatok az összehasonlítható kohorszokban is növekedést jeleztek, meghaladva az elôzô vizsgálati hullám alapján becsülhetô értéket. A 2003-as és a 2007-es kutatásokban pedig az összehasonlítható kohorszokra (18-53 vs. 22-57 évesekre) mért életprevalencia-értékek hibahatáron belül megegyeztek (2003-ban 11,1\%, 2007-ben 9\%; standard hiba $\pm 1,3$, ill. $\pm 1,2$ ), így a korábbi hullámok korrekciós eljárást nem tettek indokolttá. 
alapuló korrekciós eljárást dolgoztunk ki. A mért értékek alapján mutatkozó stagnálástól eltérốen, a korrigált értékek a tiltott drogfogyasztás elterjedtségének hibahatáron túli növekedésére engednek következtetni.

A szerhasználat struktúráját vizsgálva azt mondhatjuk, hogy 2015-ben a felnôtt népességben a legtöbben marihuánát/hasist fogyasztottak eddig életük során, közel fele ekkora, de a többi szerhez képest kimagasló az ecstasy életprevalencia-értéke. A két legnépszerúbb szert a szintetikus-kannabinoidok, az amfetamin és az új stimulánsok jóval alacsonyabb prevalenciaértékekkel - követik. A 2007-es vizsgálattal (Paksi, 2009) összehasonlítva az ecstasy elterjedtségének szignifikáns növekedése (OLAAP 2007: életprevalencia: 2,4\% hibahatár: $\pm 0,6$; OLAAP 2015: életprevalencia: 4,0\%; hibahatár: $\pm 1,0)$ és az új pszichoaktív szerek megjelenése, illetve meghatározóvá válása emelhetố ki.

Az elmúlt évben a használók kétharmada a vizsgált 14-féle drog közül egy-két félét, a 6-féle EMQ standard drog közül pedig egyfélét használt. Ez utóbbi populáció aránya OLAAP 2007-es vizsgálathoz képest (Paksi, 2009) kétharmados biztonsággal csökkent, azaz tendencia jelleggel növekedett a polidroghasználat.

Az elsô droghasználat átlagos életkora a jelenlegi felnôtt népességben 20 éves életkor, ami a 2007-ben mért 20,3-hoz (Paksi, 2009) képest nem változott szignifikánsan.

A drogokkal való kapcsolatba kerülés társadalmi demográfiai kockázati tényezóit vizsgálva azt mondhatjuk, hogy a droghasználat nemi, korosztályos és urbanizációs mintázata a leíró statisztikai adatokban - a korábbi vizsgálatokhoz hasonlóan (Paksi, 2007, 2009) - ma is megjelenik, bár - a többi társadalmi-demográfiai változó kontroll alatt tartása mellett - a nemi hovatartozás önálló hatással ma már nem bír. Jelen kutatásban a kulturális/gazdasági státus vizsgált indikátorainak többsége mentén szintén szignifikáns, a kedvezóbb státusúak átlagosnál nagyobb kitettségét jelzô mintázódást tapasztaltunk. E tekintetben folytatódni látszik az a már 2007-ben megfigyelt tendencia (Elekes, Nádas, Paksi, 2008), amikor a korábbi, a droghasználók relatíve kedvezótlen, a szülốk társadalmi státusát megôrizni nem tudó (Paksi, 2007) helyzetéhez képest változásokat tapasztaltunk.

A vizsgált pszichológia tényezók pedig azt jelzik, hogy a drogok kipróbálásának hátterében a pszichiátriai tünetek nem jelennek meg, ugyanakkor az impulzivitás - a társadalmi-demográfiai változók kontroll alatt tartása mellett is - jelentốs szerepet kap, a fogyasztók körében a skála átlagértéke szignifikánsan magasabb.

\section{A KUTATÁS KORLÁTAI}

A normál népességre irányuló vizsgálatokkal - azok természetéból adódóan - a társadalom átlag felé húzó szegmenséról kapunk információkat. A kutatások során elért populációból kimaradhatnak vagy alulreprezentálttá válhatnak bizonyos csoportok, sok esetben éppen azok, amelyek az adott magatartás tekintetében különösen érintettnek tekinthetốk (mint például az otthonuktól távol tanulmányokat folytatók, börtönben élôk, hajléktalanok vagy szélsố társadalmi helyzetú csoportok). Így van ez az OLAAP 2015 vizsgálat esetében is. Ezért a társadalom droghasználatának megismeréséhez az 
OLAAP 2015 vizsgálat mellett szükség van speciális csoportokra (pl. börtönben élôk) irányuló vizsgálatokra is.

Az önbevallásos drogepidemiológia vizsgálatok során további korlátot jelent az, hogy a nyert adatok a megkérdezettek bevallásán alapulnak. Az önbevallásos adatok minôségét számos, a mintavételi, illetve adatfelvételi eszközök és eljárások standarditásával nem kiküszöbölhetô, a kutatók által nem befolyásolható tényezô alakíthatja (Stoop, 2004; Johnson, O’Rourke, Burris és Owens, 2002), amelyek egyike a probléma társadalmi megítélése. Az elmúlt másfél évtized attitúdállapotokra vonatkozó kutatási adatai alapján (Paksi, 2001, 2003, 2009; Elekes és Paksi, 2004; Felvinczi, Paksi, Magi és Demetrovics, 2015) a 2015-ös OLAAP-vizsgálat a marginalizált társadalmi csoportokat fokozottan elutasító társadalmi/morális térben zajlott, ami megnövelte a vizsgálat során a mintavételen kívüli hibák kockázatát. Az OLAAP 2015 kutatási adatok reprezentativitásának, valamint a mintavételen kívüli hibák nagyságának adatbázison belüli eszközökkel történô vizsgálata alapján nem látunk olyan tényezôt, ami problémát okozna a keresztmetszeti elemzések során (Paksi és mtsai, 2017). A módszertani eredmények arra utalnak, hogy droghasználat aktuális jellemzôi és mintázódása tekintetében a kutatás adatai alapján érvényes és megbízható megállapítások fogalmazhatók meg. Ugyanakkor a mintavételen kívüli hibák tendenciái azt jelzik, hogy a változások elemzése, értelmezése fokozott odafigyelést, esetleg korrekciós eljárások alkalmazását teszi szükségessé. Tanulmányunkban egy ilyen, a mért adatokban mutatkozó tendenciákat jelentôsen módosító korrekciós kísérletünk eredményét is bemutattuk. Hasonló odafigyeléssel kell eljárnunk azonban a nemzetközi összehasonlítások során is, ami további korlátját jelenti az adatok értelmezésének. Ahhoz, hogy az OLAAP 2015 adatait nemzetközi kontextusban elhelyezzük, ismernünk és elemeznünk kell az összehasonlítás során felhasznált adatok megbízhatósági és érvényességi jellemzôit is. Ez az elemzés meghaladta jelen tanulmány kereteit.

\section{KÖSZÖNETNYILVÁNÍTÁS}

A tanulmány a Nemzeti Kutatási, Fejlesztési és Innovációs Hivatal (K109375; K111938; KKP126835) és az EMMI támogatásával készült.

A kutatáshoz tartozó etikai engedély ügyiratszáma: 2015/76

A kutatást az ELTE Felsôoktatási Intézményi Kiválósági Program (1783-3/2018/ FEKUTSRAT) támogatta.

\section{IRODALOM}

Andorka R. (1994). Deviáns viselkedések Magyarországon - általános értelmezési keret az elidegenedés és az anómia fogalmak segítségével. In Münnich I., Moksony F. (szerk.), Devianciák Magyarországon (pp. 32-77). Budapest: Közélet Kiadó.

Barratt, E. S. (1959). Anxiety and impulsiveness related to psychomotor efficiency. Perceptual and Motor Skills, 9, 191-198.

Decorte, T., Mortelmans, D., Tieberghien, J., \& De Moor, S. (2009). Drug use: an overview of general population surveys in Europe. Thematic paper. Luxembourg: EMCDDA. 
Derogatis, L. R., \& Melisaratos, N. (1983). The Brief Symptom Inventory: an introductory report. Psychological Medicine, 13(3), 595-605.

Elekes Zs. (2004). Alkohol és társadalom. Budapest: Országos Addiktológiai Intézet.

Elekes Zs. (2009). Egy változó kor változó ifjúsága. Fiatalok alkohol-és egyéb drogfogyasztása Magyarországon - ESPAD 2007. Budapest: L'Harmattan.

Elekes Zs. (2012). Fiatalok legális és illegális szerhasználata az ESPAD 2011 kutatás alapján. Addiktológiai kutatások Magyarországon 2012. „A függőségek kialakulása és kezelése.” Az ELTE Pszichológiai Intézet Klinikai Pszichológia és Addiktológia Tanszéke V. Tudományos Konferenciája. Budapest, 2012. február 24.

Elekes Zs. (szerk.) (2016). Európai iskolavizsgálat az alkohol- és egyéb drogfogyasztási szokásokról 2015. Magyarországi eredmények. Budapest: BCE.

Elekes Zs., \& Paksi B. (2004). A 18-54 éves felnôttek alkohol-és egyéb drogfogyasztási szokásai. Kutatási Beszámoló, NKFP. http:/ /viselkedeskutato.hu/index.php?option=com_attachments\&task=download\&id=57\&lang $=\mathrm{hu}$

Elekes Zs., Nádas E., \& Paksi B. (2008). Drogfogyasztás a populációban. In Felvinczi K., Varga O. (szerk.), Jelentés a magyarországi kábítószerhelyzetról (pp. 33-53). Budapest: SzMM.

EMCDDA (1999). Co-ordination of an expert working group to develop instruments and guidelines to improve quality and comparability of general population surveys on drugs in the EU. Follow up of EMCDDA project CT.96.EP.08 (CT.97.EP.09), EMCDDA, Lisbon, Portugal. http://www. emcdda.europa.eu/attachements.cfm/att_1385_EN_expert_group_comp_report.pdf

EMCDDA (2002). Handbook for surveys on drug use among the general population. EMCDDA project CT.99.EP.08 B, Lisbon, Portugal. http://www.emcdda.europa.eu/system/files/ publications/244/Handbook_for_surveys_on_drug_use_among_the_general_population_-_2002_106510.pdf

EMCDDA (2009a). An overview of the general populations survey (GPS) key indicator. Technical reports. Lisbon. Letöltve: 2009.09.11. http:/ /www.emcdda.europa.eu/publications/methods/ gps-overview

EMCDDA (2009b). An overview of the general populations survey (GPS) key indicator. Thematic papers. Lisbon. Letöltve: 2009.09.11. http://www.emcdda.europa.eu/system/files/publications/967/EMCDDA-TP-gps.pdf

EMCDDA (2015a). European Drug Report. Trends and Developments, 2015. Luxemburg, Letöltve: 2018.05.10. http://www.emcdda.europa.eu/attachements.cfm/att_239505_EN_ TDAT15001ENN.pdf

EMCDDA (2015b). Voluntary EMQ Module for monitoring use of New (and not so new) Psychoactive Substances (NPS) in General Adult Population Surveys and School Surveys. Lisbon, EMCDDA (kézirat). Letöltve: 2015.01.10. http://www.emcdda.europa.eu/attachements.cfm/att_249891_ EN_EMQ\%20Voluntary\%20Module\%20on \%20New\% 20Psychoactive\%20Substances \% 20 (NPS).pdf.

EMCDDA (2016). European Drug Report. Trends and Developments, 2016. Luxemburg, EMCDDA, Lisbon, Letöltve: 2018.05.10. http://www.emcdda.europa.eu/system/files/publications/2637/TDAT16001ENN.pdf

European School Survey Project on Alcohol and Other Drugs Group (2016). ESPAD Report 2015. Results from the European School Survey Project on Alcohol and OtherDrugs. Luxembourg, Luxemburg: Publications Office of the European Union. Retrieved from: Letöltve: 2018.05.10. http:/ / www.espad.org/sites/espad.org/files/TD0116475ENN.pdf

Felvinczi K., Paksi B., Magi A., \& Demetrovics Zs. (2015): Pszichoaktív szerhasználókkal kapcsolatos társadalmi attitüdök a 2015. évi „Országos Lakossági Adatfelvétel Addiktológiai Problémákról” (OLAAP 2015) címú vizsgálat elsô eredményei tükrében. MAT X. Országos Kongresszusa 2015. 
november 26-28., Siófok, Supplementum kötet, 20. http://www.mat.org.hu/doksi/2015/ Absztraktfuzet_MAT_X_2015.pdf

Fusco, A., Guio A. C., \& Marlier E. (2010). Income poverty and material deprivation in European countries. Eurostat Methodologies and working papers, Luxembourg, Publications Office of the European Union.

Guio, A. C., Gordon D., \& Marlier E. (2012). Measuring material deprivation in the EU. Indicators for the whole population and child-specific indicators. Paper presented during the working group meeting 'Statistics on Living Conditions', Eurostat, 29-31 May, Luxembourg.

Hibell, B., Andersson, B., Ahlström, S., Balakireva, O., Bjarnasson, T., Kokkevi, A., et al. (2000). The 1999 ESPAD Report. Alcohol and Other Drug Use Among Students in 30 European Countries. The European School Survey Project on Alcohol and Other Drugs. CAN, Stockholm, Sweden. Letöltve: 2018.05.10. http://www.espad.org/sites/espad.org/files/The_1999_ ESPAD_report.pdf

Hibell, B., Guttormsson U., Ahlström S., Balakireva O., Bjarnason T., Kokkevi A. et al. (2009). The 2007 ESPAD Report. Substance Use Among Students in 35 European Countries. The European School Survey Project on Alcohol and Other Drugs. CAN. EMCDDA, Stockholm. Sweden. Letöltve: 2018.05.10. http://www.espad.org/sites/espad.org/files/The_2007_ESPAD_Report-FULL_091006.pdf

Hibell, B., Guttormsson U., Ahlström S., Balakireva O., Bjarnason T., Kokkevi A. et al. (2012). The 2011 ESPAD Report. Substance Use Among Students in 36 European Countries. The European School Survey Project on Alcohol and Other Drugs. CAN. Stockholm. Sweden. Letöltve: 2018.05.10. http://www.espad.org/sites/espad.org/files/The_2011_ESPAD_Report_ FULL_2012_10_29.pdf

Johnson, T. P., O’Rourke, D., Burris, J., \& Owens, L. (2002). Culture and Survey Nonresponse. In R. M. Groves, Don A. Dillman, J. L. Eltinge, \& R. J. A. Little (Eds), Survey Nonresponse (pp. 55-69). New York: John Wiley \& Sons.

Kapitány-Fövény, M., Varga, G., Potenza M. N., Griffiths M. D., Székely A., Paksi, B. és mtsai (2018). The 21-item Barratt Impulsiveness Scale Revised (BIS-R): An alternative three-factor model. Megjelenés alatt

Kapitány B., \& Spéder Zs. (2004). Szegénység és depriváció: társadalomszerkezeti összefüggések nyomában. Életünk fordulópontjai. Múhelytanulmányok 4. Budapest, KSH-NKI, Letöltve: 2018.05.10. http://demografia.hu/kiadvanyokonline/index.php/muhelytanulmanyok/ article/view/871/452

Németh Á., \& Költố A. (szerk.) (2011). Serdülókorú fiatalok egészsége és életmódja 2010. Budapest OGYEI. Letöltve: 2018.05.10. http://www.ogyei.hu/anyagok/HBSC_2010.pdf

Németh Á., \& Költô A. (szerk.) (2014). Egészségés egészségmagatartás iskoláskorban - 2014. Budapest NEFI. Letöltve: 2018.05.10. http://www.egeszseg.hu/szakmai_oldalak/assets/cikkek/1605/egeszseg-es-egeszsgegmagatartas-iskolaskorban-2014.pdf

Paksi B. (2001). A magyar társadalom droggal kapcsolatos gondolkodásának alakulása az évezred utolsó éveiben. In Dr. Dienes E., \& Takáts Á. (szerk.), Tanulmányok és múhelybeszámolók. A XV. Munka- és szervezetpszichológiai szakmai napok elôadásai (pp. 161-171). Budapest: Országos Munkaügyi Kutató és Módszertani Központ, Foglalkoztatási Hivatal.

Paksi B. (2003). Drogok és felnôttek. A tizennyolc év feletti lakosság drogfogyasztása és droggal kapcsolatos gondolkodása az ezredfordulón, Magyarországon. Budapest: L'Harmattan.

Paksi B. (2007). A magyarországi drogfogyasztás társadalmi mintázata. In Demetrovics Zs. (szerk.), Az addiktológia alapjai. I. (pp. 379-413). Budapest: Eötvös Kiadó.

Paksi B. (2009). Populációs adatok alakulása. In Felvinczi K., \& Nyírády A. (szerk.), Drogpolitika számokban (pp. 81-141). Budapest: L’Harmattan. 
Paksi B., Rózsa S., Kun B., Arnold P., \& Demetrovics Zs. (2009). A magyar népesség addiktológiai problémái: az Országos Lakossági Adatfelvétel az Addiktológiai Problémákról (OLAAP) reprezentatív felmérés módszertana és a minta leíró jellemzői. Mentálhigiéné és Pszichoszomatika, 10(4), 273-300.

Paksi B., Demetrovics, Zs., Magi A., \& Felvinczi K. (2017). Az Országos Lakossági Adatfelvétel az Addiktológiai Problémákról 2015 (OLAAP 2015) reprezentatív lakossági felmérés módszertana és a minta leíró jellemzôi. Neuropsychopharmacologia Hungarica, 19(2), 55-85.

Paksi B., Demetrovics, Zs., Griffiths, M. D., Magi A., \& Felvinczi K. (2018). Estimating and managing the changing methodological parameters of self-report surveys of addictive behavior: - based on the waves of the National Survey on Addiction Problems in Hungary (NSAPH) in 2007 and 2015. (megjelenés alatt)

Patton, J. M., Stanford, M. S., \& Barratt, E. S. (1995). Factor Structure of the Barratt Impulsiveness Scale. Journal of Clinical Psychology, 51, 768-774.

Róbert P. (1990). Társadalmi mobilitás. In Andorka R., Kolosi T., \& Vukovich Gy. (szerk.), Társadalmi Riport (pp. 356-372). Budapest: TÁRKI.

Robinson, P. J., Shaver, R. P., \& Wrightsman, S. L. (1991). Measures of Personality and Social Attitudes. San Diego: Academic Press.

Susánszky É., Konoly T. B., Stauder A., \& Kopp M. (2006). A WHO Jóllét kérdôív rövidített (WBI-5) magyar változatának validálása a Hungarostudy 2002 országos lakossági egészségfelmérés alapján. Mentálhigiéné és Pszichoszomatika, 7(3), 247-255.

Townsend, P. (1979). Poverty in the United Kingdom: a survey of household resources and standards of living. Harmondsworth: Penguin Books.

Stoop, I. A. L. (2004) Surveying nonrespondents. Field Methods, 16(1), 23-54.

Unoka Zs., Rózsa S., Kô N., Kállai J., Fábián Á., \& Simon L. (2004). A Derogatis-féle Tünetlista hazai alkalmazásával szerzett tapasztalatok. Psychiatria Hungarica, 19, 235-243.

WHO (2000). International Guide for Monitoring Alcohol Consumption and Related Harm. Department of mental Health and Substance Dependence Noncommunicable Disease and mental Health Cluster. Letöltve: 2018.05.10. http://apps.who.int/iris/handle/10665/66529

\section{DRUG USE OF THE HUNGARIAN ADULT POPULATION BASED ON THE NATIONAL (REPRESENTATIVE) SURVEY ON ADDICTION PROBLEMS IN HUNGARY (NSAPH 2015)}

\section{PAKSI, BORBÁLA - DEMETROVICS, ZSOLT - MAGI, ANNA - FELVINCZI, KATALIN}

Background and objectives: Targeted drug epidemiology surveys among the adult population of Hungary were carried out in 2001 (ADE 2001), 2003 (ADE 2003) and in 2007 (NSAPH 2007). To assess and monitor the addictive problems of the Hungarian the latest targeted drug epidemiology research took place in 2015, after an eight years gap. The current study presents the drugs related results of the National Survey on Addiction Problems in Hungary (NSAPH 2015).

Method: The research was carried out on a nationally representative sample of the Hungarian adult population aged 16-64 yrs (br. sample 2477, net sample 2274 persons) with the age group of 18-34 being overrepresenting. The size of the weighted sample of the 18-64 years old adult population is 1490 persons. The weighted sample of the 18-64 years old population covered 1490 individuals. During the data collection in the spring of 2015 a mixed method arrangement of face-to-face and self-administered questionnaire was used. Questions related to drug use relied on our own previous research experiences (Paksi et al., 2009), 
the Epidemiological Model Questionnaire (EMQ) of the EMCDDA (EMCDDA, 1999, 2002) and its actual indicators related recommendations (EMCDDA, 2015b), It also reflected on the meta-analysis of drug epidemiology researches of other European countries (Decorte et al., 2009). Data analysis was implemented in accordance with EMCDDA (2002) standards.

Results/Conclusions: According to our results every tenth respondent (9,9\%) in the Hungarian adult population (18-64 yrs) has already consumed illicit substances at least once. The last year prevalence rate of illicit substances is 2,3\% whilst the last month prevalence rate is 1,2. Most of them consumed marijuana/ hashish, which is followed by xtc, synthetic cannabinoids, amphetamines and new stimulants. Whilst studying the social-demographical risk factors of drug use we should highlight the age specific and urbanisation patterns together with the role of cultural and economic status as well as impulsivity.

Keywords: drug use; general population survey; representative data collection; Hungary 